Eduvest - Journal of Universal Studies

Volume 1 Number 11, November 2021

p- ISSN 2775-3735 e-ISSN 2775-3727

\title{
EMPLOYEE WORK MOTIVATION IN MAINTAINING THE PERFORMANCE OF BALIKPAPAN REGIONAL HOSPITAL NURSES DURING THE COVID-19 PANDEMIC
}

Didik Hadiyatno, Tutik Yuliani, Pudjiati

Balikpapan University, Indonesia

E-mail: didikhadiyatno@uniba-bpn.ac.id, tutik.yuliani@uniba-bpn.ac.id, pudjiati@uniba-bpn.ac.id

\begin{tabular}{|c|c|}
\hline ART & ABSTRACT \\
\hline $\begin{array}{l}\text { Received: } \\
\text { October, 26 } \\
2021 \\
\text { Revised: } \\
\text { November, } 16^{\text {th }} \\
2021 \\
\text { Approved: } \\
\text { November, } 18^{\text {th }} \\
2021\end{array}$ & $\begin{array}{l}\text { This study aims to analyze the effect of Motivation, Work } \\
\text { Environment, and Compensation Variables on the } \\
\text { Performance of Nurses at Regional Hospitals in } \\
\text { Balikpapan, both Simultaneously and Partially. The } \\
\text { population is } 138 \text { people with sample } j \text { used is } 138 \text { nurses } \\
\text { and the analysis tool used is multiple linear regression. } \\
\text { From the results of the simultaneous test, it was obtained } \\
\text { that there was a strong relationship between the } \\
\text { variables of Motivation, Work Environment and } \\
\text { Compensation on the Nurse Performance variable at the } \\
\text { Hospital in Balikpapan. it can be concluded that the } \\
\text { variables of Motivation, Work Environment and } \\
\text { Compensation are proven together to have a significant } \\
\text { effect on the variable of Nurse Performance at Hospitals } \\
\text { in Balikpapan. Meanwhile, based on the results of the } \\
\text { partial test, it was found that the variables of motivation, } \\
\text { work environment, and compensation proved to have an } \\
\text { influence on the performance of nurses at the Balikpapan } \\
\text { Regional Hospital, that it was the compensation variable } \\
\text { that had a dominant influence on the performance of } \\
\text { hospital nurses in Balikpapan. }\end{array}$ \\
\hline $\mathrm{KEY}$ & ipensation, rento \\
\hline
\end{tabular}

Didik Hadiyatno, Tutik Yuliani, Pudjiati. (2021). Employee Work Motivation in Maintaining the Performance of Balikpapan Regional Hospital Nurses during the Covid-19 Pandemic. Journal Eduvest. 1(11): 1268-1275

How to cite:

E-ISSN:

Published by: 


\begin{tabular}{ll}
\hline (C) (D) (O) & $\begin{array}{l}\text { This work is licensed under a Creative Commons } \\
\text { Attribution-ShareAlike 4.0 International }\end{array}$ \\
\hline
\end{tabular}

\section{INTRODUCTION}

Currently, public services that are in the spotlight are hospitals, especially hospitals that are referrals for COVID-19 patients. The obstacle experienced by the referral hospital is the limited number of nurses while the number of patients continues to grow every day (Utami, Pinzon, \& Meliala, 2021). The high number of Covid patients is a serious problem for hospitals due to the limited number of nurses to provide health services. Health services are closely related to nurses because they are one of the most important resources owned by hospitals. Nurses play an important role because they are directly involved with patients and the role of a nurse in providing services will determine the quality of service (Haji, Madiistriyatno, Widayati, \& Usman, 2021; Madiistriyatno \& Setiawan, 2021), if the nurse lacks or even has low immunity, then health services will not be optimal. Hospitals must utilize the resources they have to overcome the health problems faced by society today, namely by paying attention to their medical personnel.

(Watung, Kawet, \& Saerang, 2016) employee performance refers to employee performance which is regulated based on standards or criteria set by an organization. High employee performance can improve overall organizational performance (Madiistriyatno, 2017). And vice versa, if employee performance is low, it will reduce the performance of an organization or company (Madiistriyatno, 2015). (Kustomo \& Suwitho, 2018) employee performance is the result of work achieved by individuals who are adjusted to the role or task of the individual in a company or organization within a certain period, which is associated with a measure of value or a certain standard of the company where the individual works (Madiistriyatno \& Wahyuningsih, 2021).

(Fauzi \& Khuzaini, 2019) work motivation is a willingness and encouragement from within a person to achieve company goals without neglecting his ability to fulfill needs (Pudjiati \& Yusuf, 2021). Motivation and work experience are things that play an important role in increasing work effectiveness. Because people who have motivation will try their best so that their work can be as successful as possible, will form an increase in work productivity. (Haya \& YPE, 2020) the work environment is one that affects employee performance (Bonnario, Madiistriyatno, \& Zulfikar, 2021), because a comfortable and safe work environment can develop employee creativity and good cooperation between employees. A comfortable work environment can make them calmer, more effective, diligent and serious in dealing with their duties (Pratama \& Supriyatin, 2020) compensation is a problem that often occurs in small and large companies. The amount of compensation given to employees can reflect an employee's work given to an organization or company (Madiistriyatno \& Sofianto, 2021).

According (Nginayati, 2019) the existence of a good compensation system in a company is expected to improve the performance of employees. If the company provides additional compensation to employees, then employees tend to try to improve their performance. This study will look at the impact of employees in doing work during the 
current pandemic, of course there is a gap in carrying out their performance from the aspect of motivation, work environment and compensation obtained in the workplace. job improvement efforts.

\section{RESEARCH METHOD}

In a study, the selected population has a close relationship with the problem under study. The population in this study were all non-medical employees of the Regional Hospital in Balikpapan, amounting to 138 employees. Sampling was used with saturated sampling with the census method as many as 138 respondents. Data analysis carried out by researchers was carried out with the help of the SPSS program as a tool to regress the formulated model. The analytical model used in this study is in the form of Multiple Linear Regression. This model is used to determine the effect of the independent variable on the dependent variable, in this case it includes the independent variable on the dependent variable. The specified multiple linear regression equation is as follows:

Where :

$$
\mathrm{Y}=\mathrm{a}+\mathrm{b} 1 \mathrm{X} 1+\mathrm{b} 2 \mathrm{X} 2+\mathrm{b} 3 \mathrm{X} 3+\mathrm{ei}
$$

$$
\begin{aligned}
& \text { Y = Employee Performance } \\
& \text { X1 = Compensation Variable } \\
& \text { X2 = Discipline Variable } \\
& \text { X3 = Motivation Variable } \\
& \text { a = Constant } \\
& \text { b1b2b3 = Regression Coefficient } \\
& \text { ei = Interference Parameter }
\end{aligned}
$$

\section{RESULT AND DISCUSSION}

This hospital was established to meet the community's need for referral health services in the era of social health insurance. In 2007 a Feasibility Study was made which was carried out by Bappeda. and continued with the making of a hospital master plan and UKL-UPL in 2008 which was carried out by the Balikpapan City Health Office. In 2009 a Detailed Engineering Design (DED) was made which was carried out by the Public Works Department. The development process was carried out in a multi-year manner, starting from 2012 to 2014. Construction of the Balikpapan Regional Hospital, which is located on Jalan Mayjend. Sutoyo (Mount Malang) Gunung Sari Ulu Village, Central Balikpapan District. Through Regional Regulation Number 7 of 2014 it was determined to be a Class C Hospital whose inauguration on February 10, 2015 coincided with the 118th anniversary of Balikpapan City. The Balikpapan Regional Hospital is located as a Regional Work Unit for the Balikpapan City government in the field of public health services. In 2015 the Mayor of Balikpapan Decree No. 188.45-67/2015 Regarding the Determination of the Balikpapan Regional General Hospital as a hospital that implements the Financial Management Pattern of the Regional Public Service Agency in stages. Then in 2016 the Mayor of Balikpapan Decree Number 188.45-426/2016 was issued regarding the designation of the Balikpapan Regional Hospital as a hospital that fully implements the Financial Management Pattern of the Regional Public Service Agency. Based on the research data, the frequency distribution of the respondents' last education is seen as follows: 
Table 2 Multiple Linear Regression Analysis

\begin{tabular}{clll}
\hline No & Respondent's Last Education & Total & Percentage (\%) \\
\hline 1 & SD & 4 & $2,9 \%$ \\
2 & SMP & 5 & $3,6 \%$ \\
3 & SMA/SMK & 95 & $68,8 \%$ \\
4 & D1/D2/D3 & 15 & $10,8 \%$ \\
5 & S1 & 17 & $12,3 \%$ \\
6 & S2 & 2 & $1,4 \%$ \\
\multicolumn{2}{c}{ Total } & 138 & $100 \%$ \\
\hline
\end{tabular}

Source: Primary data $2021 \mathrm{H}$

Based on the results presented in table 1, it can be explained that of the 138 respondents, 4 people $(2.9 \%)$ have elementary education, 5 people have junior high school education, 95 people have high school education, 15 people have D1/D2/D3, 17 people have 12 education., $3 \%$ and 2 people have a master's degree.

\section{Multiple Linear Regression Analysis}

Multiple linear regression test was conducted to determine how much influence the variables Compensation (X1), Discipline (X2) and Motivation (X3) on Employee Performance (Y) at the Balikpapan Regional Hospital. From these results, a linear equation can be made which will later explain the effect of these independent variables on the dependent variable. Based on these equations, it can also be seen that the constants of each variable explain the relationship between the variables. The results of the analysis are contained in the table as follows:

\begin{tabular}{|c|c|c|c|c|c|c|c|}
\hline \multirow{2}{*}{ Indicator } & \multicolumn{2}{|c|}{ Unstandardized } & \multirow{2}{*}{$\begin{array}{l}\text { Standardized } \\
\text { Coefficient }\end{array}$} & \multirow{2}{*}{$\mathrm{t}$} & \multirow{2}{*}{ Sig } & \multicolumn{2}{|c|}{ Correlation } \\
\hline & $\mathrm{B}$ & $\begin{array}{l}\text { Std. } \\
\text { Error }\end{array}$ & & & & Partial & Part \\
\hline Constant & 1,409 & 0,315 & & 4,480 & 0,000 & & \\
\hline Compensation & 0,034 & 0,065 & 0,040 & 0,521 & 0,603 & 0,045 & 0,034 \\
\hline Discipline & 0,186 & 0.084 & 0,172 & 2,222 & 0,028 & 0,188 & 0,146 \\
\hline Motivation & 0,493 & 0,070 & 0,536 & 7,066 & 0,000 & 0,521 & 0,464 \\
\hline \multicolumn{4}{|l|}{$\mathrm{R}=0,650$} & \multicolumn{4}{|c|}{$\mathrm{F}$ Count $=32.648$} \\
\hline \multicolumn{4}{|c|}{ R Square $=0,422$} & \multicolumn{4}{|c|}{ F Table $=2,67$} \\
\hline \multicolumn{4}{|c|}{ Adjusted R Square $=0,409$} & \multicolumn{4}{|c|}{$\mathrm{T}$ Table $=1,977$} \\
\hline \multicolumn{4}{|c|}{ Durbin Watson $=1,983$} & \multicolumn{4}{|c|}{ Sig. $t=0,05$} \\
\hline
\end{tabular}

Source: Primary data $2021 \mathrm{H}$

The results of the Multiple Linear Regression analysis obtained are as follows:

$$
\mathrm{Y}=1.409+0.034 \mathrm{X} 1+0.186 \mathrm{X} 2+0.493 \mathrm{X3}
$$

Based on the results of the multiple linear regression equation above, it can be interpreted as follows:

The constant coefficient value of 1.409 indicates if the value of the Compensation (X1), Discipline (X2), and Motivation (X3) variable has a constant value or zero, then the Employee Performance variable (Y) at the Balikpapan Regional Hospital is 1.409. Meanwhile, based on statistical analysis, the value of the regression coefficient is described as follows: The relationship between compensation variable (X1) on employee performance $(\mathrm{Y})$ at the Balikpapan Regional Hospital is shown in the regression 
coefficient value of 0.034 which is positive with a significant value of $0.603<0.05$ and can also be seen from tcount $<\mathrm{t}$ ttable, namely $0.521<1.977$, it means that compensation (X1) has a positive but not significant effect on employee performance (Y). positive with a significant value of $0.028<0.05$ and can also be seen from tcount $>$ ttable which is $2.222>1.977$, meaning that Discipline (X2) has a positive and significant effect on Employee Performance (Y). Balikpapan Regional Hospital is shown in the regression coefficient value of 0.493 which is positive with a sig . value the significance is 0.000 $<0.05$ and can also be seen from tcount $>$ ttable which is $7.066>1.977$ which means that motivation (X3) has a positive and significant effect on employee performance (Y).

\section{Discussion}

The F test (Simultaneous Test) was conducted to see the effect of the independent variables (Compensation, Discipline, Motivation) on the dependent variable (Employee Performance) together. Shown by comparing the value of fcount with the value of ftable.

ftable $=\mathrm{f}(\mathrm{k} ; \mathrm{n}-\mathrm{k})=\mathrm{f}(3 ; 135)=2.67$. From the results of these calculations, the ftable value is 2.67 with a fcount value of 32.648 .

Furthermore, to determine $\mathrm{H} 0$ and $\mathrm{Ha}$ can be accepted or not, it can be done by determining the significant level of 5\% (0.05). Comparing the significant level $(\alpha=0.05)$ with the significant level of $\mathrm{F}$ which is known directly using the SPSS program with the following criteria: A significant value of $\mathrm{F}<0.05$ means that $\mathrm{H} 0$ is rejected and $\mathrm{Ha}$ is accepted, this means that all independent variables are simultaneously and significantly affect the dependent variable. F value $>0.05$ means $\mathrm{H} 0$ is accepted and $\mathrm{H} 1$ is rejected, this means that all independent variables simultaneously and significantly affect the dependent variable. Based on the comparison between the values of sig. $\mathrm{F}<0.05$ if seen from table 2 then $\mathrm{H} 1$ is accepted because $0.000<0.05$.

Based on this, it means that there is a joint influence between Compensation, Discipline, and Motivation on Employee Performance at the Balikpapan Regional Hospital which has been proven true and can be accepted. The t statistical test basically shows how far the influence of one explanatory variable is. or independent individually in explaining the variation of the dependent variable. The test uses a significance level of $0.05(\alpha=5 \%) .=1.977$. Based on the results of hypothesis testing, compensation, discipline, and motivation variables have an influence on employee performance. From the results of the analysis and discussion, it can be concluded that compensation, discipline, motivation together affect employee performance at the Balikpapan Regional Hospital.

This is in accordance with research conducted (Tindow, Mekel, \& Sendow, 2014) entitled "Work Discipline, Motivation and Compensation Effect on Employee Performance at Pt. Bank Sulut Calaca Branch "shows that work discipline, motivation and compensation can improve employee performance, this can help companies achieve company goals or targets

Effect of Compensation (X1) on Employee Performance (Y) at the Regional Hospital of Balikpapan with partial results with significant testing tcount $=0.603<$ ttable $=1.977$ at sig $0.603<0.05$ with a partial correlation coefficient value of $0.034(3.4 \%)$ which means that the Compensation variable (X1) has no effect on Employee Performance (Y) at the Balikpapan Regional Hospital. The facilities provided by the company have not been felt to be fair to employees and are not in accordance with what employees expect at the Balikpapan Regional Hospital. Indicators of this discipline variable consist of salary, incentives, allowances and facilities. This is in accordance with research conducted by (Katidjan, Pawirosumarto, \& Isnaryadi, 2017) entitled "The Influence of Compensation, Career Development and Communication on Employee 
Performance". Compensation for employees is a source of motivation for employees but may not necessarily affect the level of employee performance due to different levels of employee motivation preferences.

The effect of Discipline (X2) on Employee Performance (Y) at the Regional Hospital of Balikpapan with partial results with significant testing tcount $=2.222>$ ttable $=1.977$ at sig $0.028<0.05$ with a partial correlation coefficient value of $0.186(18.6 \%)$ which means that the Discipline variable (X2) is proven to have an influence on Employee Performance (Y) at the Balikpapan Regional Hospital.

It means that the second hypothesis: that there is an influence of work motivation on employee performance at the Balikpapan Regional Hospital is proven true and can be accepted. The results of this study indicate that discipline has a positive and significant effect on employee performance at the Balikpapan Regional Hospital. This shows that high work discipline can improve employee performance. The indicators of this discipline variable consist of obeying the rules of time, obeying company regulations, obeying the rules of behavior and obeying other regulations in the company.

This is in accordance with research conducted by (Pudjiati \& Yusuf, 2021) entitled "The Influence of Organizational Culture, Work Discipline, and Employee Performance of PT PLN (Persero) UP3 Balikpapan." stated that Work Discipline affects the performance of employees of PT PLN (Persero) UP3 Balikpapan.

The Effect of Motivation (X3) on Employee Performance (Y) Balikpapan Regional Hospital with partial results with significant testing t-count $=7.066>$ ttable $=$ 1.977 at sig $0.000<0.05$ with a partial correlation coefficient value of $0.493(49.3 \%)$ which means that the Motivation variable (X3) is proven to have an influence on Employee Performance (Y) at the Balikpapan Regional Hospital .

It means that the third hypothesis: that there is an influence of motivation on employee performance at the Balikpapan Regional Hospital is proven true and can be accepted. The results of this study indicate that motivation has a positive and significant effect on employee performance at the Balikpapan Regional Hospital. Work motivation is very influential on employee performance, this shows that the higher a person's motivation, the better his performance and vice versa if someone's motivation is low, his performance will also decrease. The indicators of this motivational variable consist of physiological needs, safety needs, social needs, esteem-needs and self-actualization needs.

This is in accordance with research conducted by (Gultom, 2015) entitled "The influence of corporate organizational culture and motivation on employee performance at PT. Perusahaan Gas Negara (Persero) Tbk Medan" states that motivation has a significant effect on employee performance. Thus, if employee motivation is greater in a company, it can improve employee performance in the company

Based on the results of the partial test, it was found that the motivation variable (X3) is the most dominant variable, seen from the tcount which is the largest 7.066 with a significance value of 0.000 and has a regression coefficient of 0.493 . Thus the fifth hypothesis is proven true and can be accepted.

\section{CONCLUSION}

Based on the results of the analysis and discussion in this study, the authors can make a conclusion as the final result of this study are as follows: Compensation (X1), Discipline (X2), Motivation (X3) together have a simultaneous effect on Employee Performance at Regional Hospitals Balikpapan. Compensation (X1) has no significant 
effect on employee performance at the Balikpapan Regional Hospital. Discipline (X2) has a significant effect on employee performance at the Balikpapan Regional Hospital. Motivation (X3) has a significant effect on employee performance at the Balikpapan Regional Hospital. Motivation (X3) has the most dominant effect among the other dependent variables.

\section{REFERENCES}

Bonnario, Moh, Madiistriyatno, Harries, \& Zulfikar, Azis. (2021). Human Resource Training and Planning for Work Productivity of Employees Ministry of Coordinating Ministry of Human Development and Culture. Eduvest-Journal Of Universal Studies, 1(9), 961-969.

Fauzi, Muhammad, \& Khuzaini, Khuzaini. (2019). PENGARUH KOMPENSASI, MOTIVASI DAN DISIPLIN KERJA TERHADAP KINERJA KARYAWAN (STUDI PT. RADIO CAMAR SURABAYA). Jurnal Ilmu Dan Riset Manajemen (JIRM), 8(10).

Gultom, Dedek Kurniawan. (2015). Pengaruh budaya organisasi perusahaan dan motivasi terhadap kinerja karyawan pada PT. Perusahaan Gas Negara (Persero) Tbk Medan. Jurnal Ilmiah Manajemen Dan Bisnis, 14(2).

Haji, Wachyu Hari, Madiistriyatno, Harries, Widayati, C. Catur, \& Usman, Muhammad. (2021). THE INFLUENCE OF KNOWLEDGE MANAGEMENT, SKILL, AND ATTITUDE ON EMPLOYEE PERFORMANCE. Dinasti International Journal of Digital Business Management, 2(3), 569-579.

Haya, Mey Isnaini, \& YPE, Yosephien Angelina. (2020). ANALISA MOTIVASI, KOMPENSASI, DAN LINGKUNGAN KERJA TERHADAP KINERJA PEGAWAI PADA DINAS PEMBERDYAAN MASYARAKAT DAN DESA DI KABUPATEN KARANGANYAR. KELOLA, 7(1), 68-74.

Katidjan, Purwanto S., Pawirosumarto, Suharno, \& Isnaryadi, Albertus. (2017). Pengaruh Kompensasi, Pengembangan Karir Dan Komunikasi Terhadap Kinerja Karyawan. MIX: Jurnal Ilmiah Manajemen, 7(3), 224241.

Kustomo, Wido, \& Suwitho, Suwitho. (2018). DISIPLIN KERJA, MOTIVASI, DAN KOMPENSASI TERHADAP KINERJA KARYAWAN PT. SAMUDERA KRIDA UTAMA. Jurnal Ilmu Dan Riset Manajemen (JIRM), $7(12)$.

Madiistriyatno, Harries. (2015). Pengaruh stres kerja, disiplin kerja dan kepuasan kerja terhadap intensi turnover. Jurnal Mix, (1), 54-69.

Madiistriyatno, Harries. (2017). The influence of leadership, competencies, work motivation to job satisfaction and implications to the midwives performance in north Maluku province. International Journal of Economic Research, 14(13), 293-298.

Madiistriyatno, Harries, \& Setiawan, Adi. (2021). PENINGKATAN KINERJA BIDANG KESEHATAN, MOTIVASI DAN PELAYANAN PRIMA. Syntax, 3(4).

Madiistriyatno, Harries, \& Sofianto, Sofianto. (2021). Effect of Supervision and Discipline on Improving Employee Work Effectiveness at Kebayoran Baru Tax Service Office. Eduvest-Journal Of Universal Studies, 1(6), 521-526. 
Madiistriyatno, Harries, \& Wahyuningsih, Sri. (2021). Dinamika Organisasi. Indigo Media.

Nginayati, Bekti Dini. (2019). Optimasi Formulasi Minuman Fungsional Berbasis Asam Kandis Dengan Penambahan Jahe Merah Dan Kunyit Menggunakan Respon Surface Methodology. Universitas Brawijaya.

Pratama, Boby Andhika, \& Supriyatin, Supriyatin. (2020). PENGARUH LINGKUNGAN KERJA, DISIPLIN KERJA DAN KOMPENSASI TERHADAP KINERJA KARYAWAN PT. DREAM TOUR \& TRAVEL SURABAYA. Jurnal Ilmu Dan Riset Manajemen (JIRM), 9(1).

Pudjiati, Pudjiati, \& Yusuf, Tamzil. (2021). KINERJA FAKTOR-FAKTOR YANG MEMPENGARUHI KINERJA PEGAWAI PADA KANTOR KESYAHBANDARAN DAN OTORITAS PELABUHAN KELAS I BALIKPAPAN: INDONESIA. Jurnal GeoEkonomi, 12(2), 180-193.

Tindow, Mohammad Iman, Mekel, Peggy A., \& Sendow, Greis M. (2014). Disiplin kerja, motivasi dan kompensasi pengaruhnya terhadap kinerja karyawan pada pt. bank sulut cabang calaca. Jurnal EMBA: Jurnal Riset Ekonomi, Manajemen, Bisnis Dan Akuntansi, 2(2).

Utami, Yohana Puji Dyah, Pinzon, Rizaldy T., \& Meliala, Andreasta. (2021). Evaluasi Kesiapan Rumah Sakit Menghadapi Bencana Non-Alam: Studi Kasus COVID-19 di Rumah Sakit Bethesda Yogyakarta. Jurnal Kebijakan Kesehatan Indonesia: JKKI, 10(2), 100-106.

Watung, Rannie, Kawet, Lotje, \& Saerang, Ivonne S. (2016). PENGARUH LINGKUNGAN KERJA, MOTIVASI, PELATIHAN, DAN KOMPENSASI TERHADAP KINERJA PEGAWAI. Jurnal EMBA: Jurnal Riset Ekonomi, Manajemen, Bisnis Dan Akuntansi, 4(2). 